\title{
Profile and outcome of liver diseases in pregnancy - A hospital based study
}

\author{
Ashima Kaura', Vishal ${ }^{2}$, H. S. Pannu², Deepinder Kaur ${ }^{3}$, Amandeep ${ }^{1}$, Rajoo Singh Chhina ${ }^{4}$ \\ Department of Obstetrics \& Gynaecology ${ }^{1}$, Department of Medicine ${ }^{2}$, Department of Microbiology ${ }^{3}$, \\ Department of Gastroentrology, Dayanand Medical College and Hospital, Ludhiana, Punjab, India
}

\begin{abstract}
Background \& Objective: Liver disease in pregnancy can have serious consequences. We studied the profile of liver disease in pregnant women and its correlation with outcome of pregnancy during the hospital stay in a tertiary care hospital.
\end{abstract}

Methods: Pregnant women with liver disease admitted in the departments of Medicine, Gastroenterology and Obstetrics \& Gynaecology between January 2011 and June 2012 in a tertiary care hospital of North India were evaluated for various parameters.

Results: Out of 2663 pregnant women, 92 patients (3.45\%) were diagnosed to have liver disease. Acute viral hepatitis (AVH) was found in 42 (45.6\%) and pregnancy specific liver disease in 39 (42.4\%) patients. Hypertensive disorder of pregnancy including HELLP Syndrome (Hemolysis, Elevated liver enzymes, Low platelet count) was seen in 27 patients $(29.3 \%)$. Four patients had leptospirosis and hepatitis E co-infection. Overall maternal and perinatal mortality was $7.6 \%(7 / 92)$ and $25 \%$ (23/92) respectively.

Interpretation and Conclusion : Acute viral hepatitis (45.6\%) was the most common cause of liver disease in pregnancy in our study.

Keywords: Hepatitis, Liver disease, Maternal mortality

\section{INTRODUCTION}

Varying etiologies of liver diseases are frequently seen in pregnancy. Acute viral hepatitis is the most common cause of jaundice in pregnancy. The course of most viral hepatitis infections is unaffected by pregnancy, however, a more severe course has been observed in patients with hepatitis E. ${ }^{1,2}$ The reported maternal mortality from HEV liver failure is $41-59 \%$, with a perinatal mortality of $69 \%$. $^{3,4}$ This study was undertaken to study the profile of liver disease in pregnancy and its relation to maternal and fetal outcome during the hospital stay.

\section{MATERIAL AND METHODS}

Pregnant women with liver diseases admitted in the departments of Medicine, Gastroenterology and Obstetrics \& Gynaecology in a tertiary care hospital (January 2011 to June 2012) were enrolled in this study. A detailed history was taken and a general physical \&

\section{Corresponding Author :}

Dr. Ashima Kaura,

Professor,

Department of Obstetrics and Gynaecology,

Dayanand Medical College \& Hospital, Ludhiana

Email:kaurasameer@gmail.com obstetrical examination was carried out after taking informed consent. This study was approved by the institutional ethical committee.

Following blood investigations were performed: Complete blood count, Liver function tests (LFTs), coagulation profile, blood glucose, viral markers (HBsAg, anti-HCV, anti-HIV 1\&2, anti-HAV \& anti-HEV). Ultrasonography of the abdomen for fetal well-being was done. Statistical analysis was done by using ANOVA and t-test.

\section{RESULTS}

Out of 2663 pregnant women included in the study, 92 were diagnosed with liver related diseases. Thus, the incidence of liver diseases in pregnancy was $3.45 \%$.

$$
\text { Table - I }
$$

Association of Chief Complaints with Maternal Morality

\begin{tabular}{lcc}
\hline Chief Complaints & $\begin{array}{c}\text { No. of } \\
\text { patients (\%) }\end{array}$ & $\begin{array}{c}\text { Maternal } \\
\text { mortality (\%) }\end{array}$ \\
\hline Jaundice & $54(58.7)$ & $6 / 54(11.1)$ \\
Fever & $23(25)$ & $4 / 23(17.4)$ \\
Pain Abdomen & $19(20.6)$ & - \\
Vomiting & $19(20.6)$ & $4 / 19(21.0)$ \\
Pruritis & $6(6.5)$ & - \\
CNS Symptoms & $21(22.8 \%)$ & $3 / 21(14.3)$ \\
\hline
\end{tabular}


Table - II

Incidence of Liver Related Diagnosis in Various Stages of Pregnancy

\begin{tabular}{|c|c|c|c|c|c|}
\hline $\begin{array}{l}\text { Liver-related } \\
\text { Diagnosis }\end{array}$ & $\begin{array}{l}0-13 \\
\text { weeks }\end{array}$ & $\begin{array}{c}14-28 \\
\text { weeks }\end{array}$ & $\begin{array}{l}29-40 \\
\text { weeks }\end{array}$ & $\begin{array}{c}\text { Post- } \\
\text { Partum }\end{array}$ & $\begin{array}{c}\text { Total } \\
\text { No. }(\%)\end{array}$ \\
\hline Acute viral hepatitis & 0 & 3 & 34 & 1 & $38(41.3)$ \\
\hline Hypertensive disorder of pregnancy & 0 & 3 & 24 & 0 & $27(29.3)$ \\
\hline Acute fatty liver of pregnancy & 0 & 0 & 1 & 0 & $1(1.1)$ \\
\hline Cholestatic jaundice & 0 & 1 & 7 & 1 & $9(9.8)$ \\
\hline Septicemic hepatitis & 0 & 1 & 1 & 1 & $3(3.3)$ \\
\hline Dengue fever & 0 & 0 & 1 & 1 & $2(2.2)$ \\
\hline Malaria & 0 & 0 & 2 & 0 & $2(2.2)$ \\
\hline Chronic Liver Disease & 0 & 0 & 1 & 0 & $1(1.1)$ \\
\hline $\begin{array}{l}\text { Co-infection of acute viral hepatitis with } \\
\text { leptospirosis }\end{array}$ & 0 & 1 & 3 & 0 & $4(4.3)$ \\
\hline Idiopathic & 0 & 0 & 5 & 0 & $5(5.4)$ \\
\hline Total & 0 & 9 & 79 & 4 & $92(100)$ \\
\hline
\end{tabular}

Majority of the patients $(90.2 \%, 83 / 92)$ were in the age group of $20-30$ years and $84.8 \%$ (78/92) developed liver diseases in the third trimester of their pregnancy. Signs and symptoms of the patients are described in Table I. The most common liver disease in pregnancy was acute viral hepatitis. (Table II)

The most common cause for acute viral hepatitis was hepatitis E (97.6\%) followed by Hepatitis B (0.02\%). None was positive for hepatitis A or C.
There were 7 maternal deaths during hospital stay among 92 pregnant women with liver disease (Figure I). The maternal mortality and perinatal mortality were $7.6 \%$ and $25 \%$ respectively. The perinatal mortality rates in various liver diseases in pregnancy are shown in Figure II.

\section{DISCUSSION}

Liver dysfunction in pregnancy has serious consequences. In a study done by Ch'ng et $a l^{5}$ liver

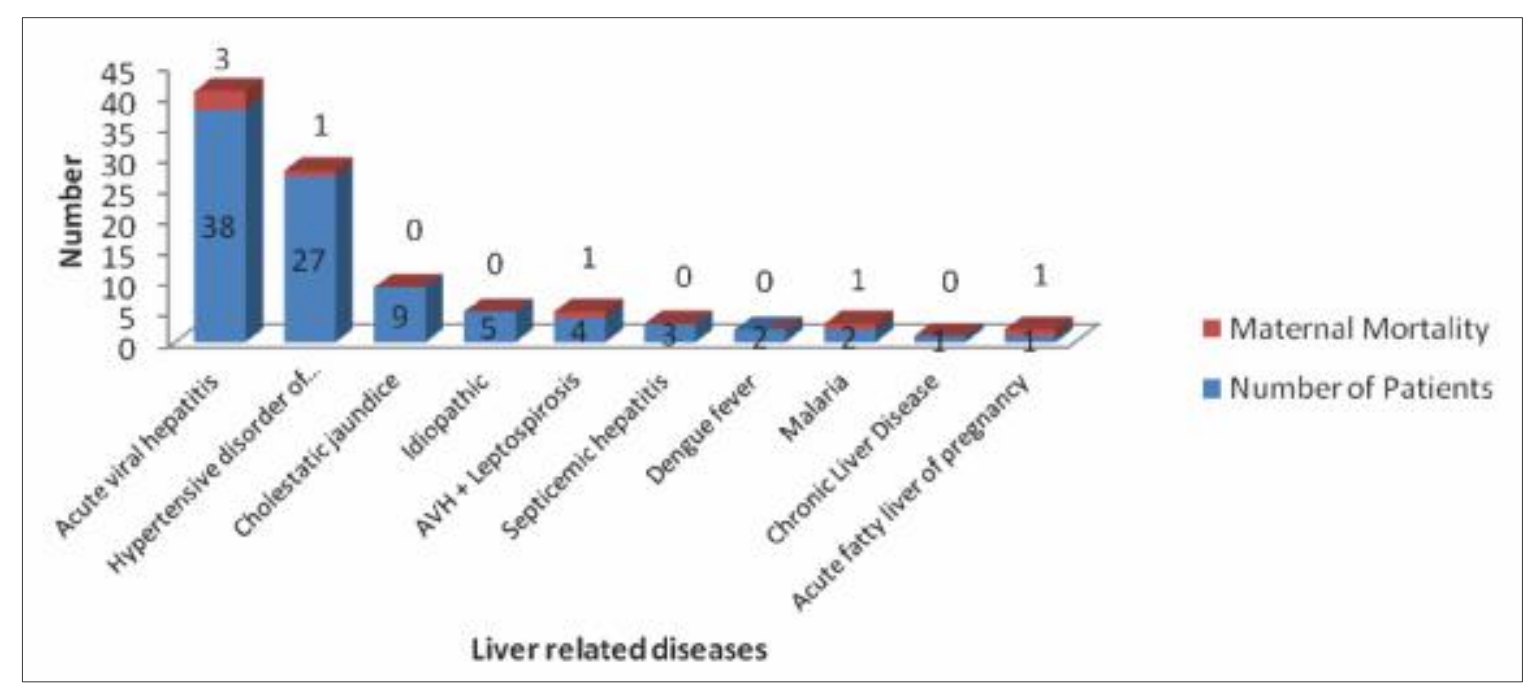

Figure I: Correlation of Liver Related Diagnosis and Maternal Mortality 


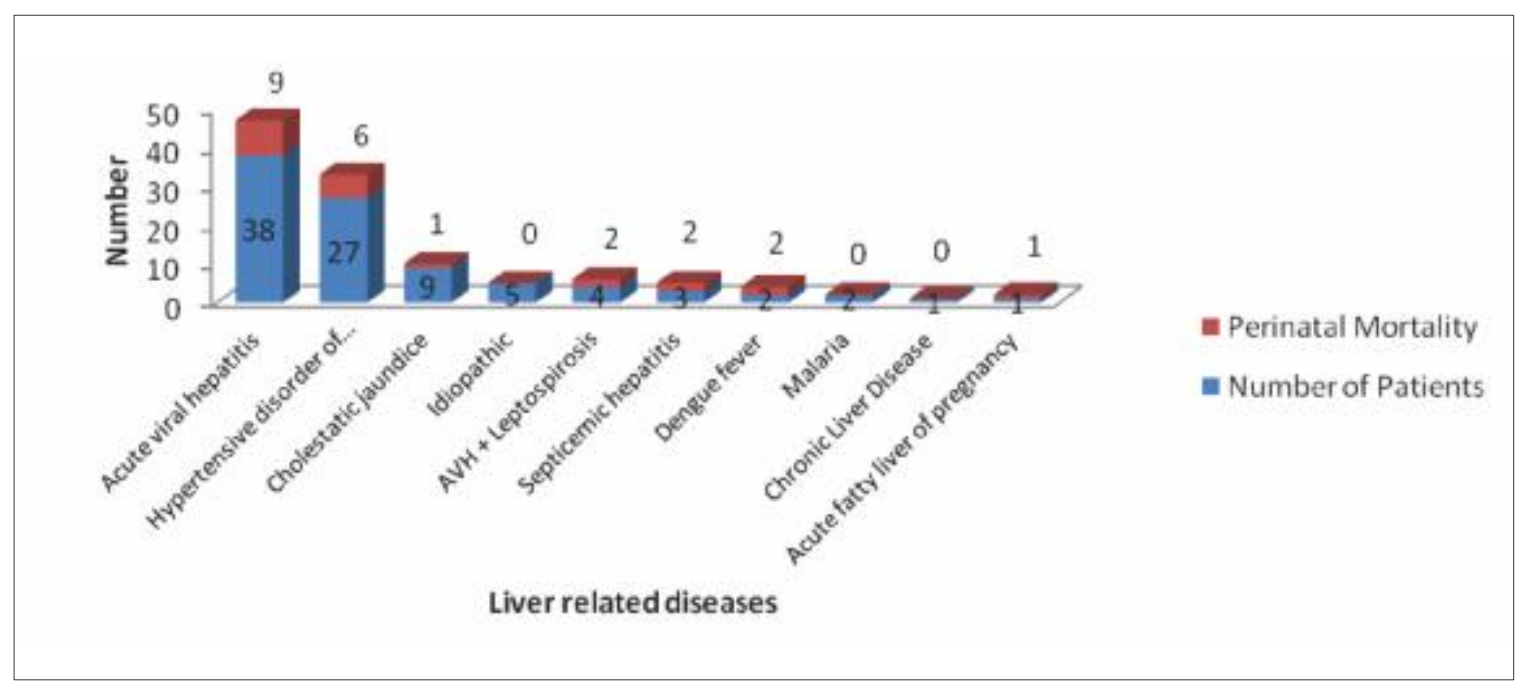

Figure II: Correlation of Liver Related Diagnosis and Perinatal Mortality

dysfunction was seen in $3 \%$ of pregnant women. This correlates with incidence of liver disorders in pregnant women in our study.

Liver diseases in pregnancy can be related to pregnancy or a pre-existing disorder. In the study done by Harish et al, ${ }^{6}$ majority of liver disorders in pregnancy were due to hyperemesis gravidarum (55.8\%), followed by viral hepatitis (47\%), HELLP syndrome (28.3\%) and acute fatty liver of pregnancy $(14.8 \%)$. Most of these patients presented in third trimester, which also correlates with our study. In our study acute viral hepatitis in pregnancy was seen in $41.3 \%$ and majority of these presented in third trimester of pregnancy, hypertensive disorders were seen in $29.3 \%$, cholestatic jaundice in $9.8 \%$, septicaemic hepatitis in $3.3 \%$, acute fatty liver of pregnancy in $1.1 \%$ cases.

Hepatitis $\mathrm{E}$ is known to be the most common cause of acute viral hepatitis during pregnancy (5\% to $86 \%) .^{7-9}$ This is similar to our study where hepatitis E was the most common cause of acute viral hepatitis $(97.6 \%)$.

All the liver disorders in pregnancy are complicated with maternal and perinatal mortality. Harish et $a l^{6}$ reported an overall maternal and perinatal mortality rates of $20.2 \%$ and $24.6 \%$ respectively. In our study maternal mortality was $7.6 \%$ and perinatal mortality of $25 \%$. The maternal mortality was highest in acute fatty liver of pregnancy $(100 \%)$ followed by malaria $(50 \%)$, coinfection of leptospirosis and acute viral hepatitis (25\%).
Ch'ng et $a l^{5}$ reported maternal and perinatal mortality of $0-13 \%$ and $0-9 \%$ in acute fatty liver of pregnancy.

Hepatitis E in pregnancy is often complicated by fulminant hepatic failure and high maternal and perinatal mortality. ${ }^{7,910}$ The reported maternal mortality due to HEV is $41-54 \%$ and perinatal mortality of $69 \% .^{3,9,11}$ High maternal and perinatal mortality is due to increased concentration of cytokines in pregnancy with hepatitis E. ${ }^{12}$ In utero transmission of HEV to the fetus might add further toxic metabolites to maternal circulation resulting in increased maternal morbidity and mortality. ${ }^{13}$

\section{CONCLUSION}

In our study the incidence of liver diseases in pregnancy was $3.45 \%$. Acute viral hepatitis was the most common cause of liver disease in pregnancy (45.6\%). The most common cause of viral hepatitis was found to be hepatitis E viral infection $(97.6 \%)$.

\section{REFERENCES}

1. Sookoian S. Liver disease during pregnancy: acute viral hepatitis. Ann Hepatol 2006;5(3):231-6.

2. Jayanthi V, Udayakumar N. Acute liver failure in pregnancy: an overview. Minerva Gastroenterol Dietol 2008:54(1):75-84.

3. Devarbhavi H, Kremers WK, Dierkhising R, Padamanabhan L. Pregnancy-associated acute liver disease and acute viral hepatitis: differentiation, course and outcome. J Hepatol 2008;49(6): 930-5.

4. Navaneethan U, Al Muhajer M, Shata MT. Hepatitis E and pregnancy: understanding the pathogenesis. Liver Int 2008;28(9):1190-9. 
5. Ch'ng CL, Morgan M, Hainsworth I, Kingham JG, Prospective study of liver dysfunction in pregnancy in Southwest Wales. Gut 2002;51(6):876-80.

6. Harish K, Nitha R, Harikumar R, Sunil Kumar K, VargheseT, Sreedevi NS, et al. Prospective evaluation of abnormal liver function test in pregnancy. Trop Gastroentrol 2005;26(5):18893.

7. Jaiswal SP, Jain AK, Naik G, Soni N, Chitnis DS. Viral hepatitis during pregnancy. Int J Gynaecol Obstet 2001;72(2):103-8.

8. Nayak NC, Panda SK, Datta R, Zuckerman AJ, Guha DK, Madangopalan N, et al. Aetiology and outcome of acute viral hepatitis in pregnancy. J Gastroenterol Hepatol 1989;4(4):34552.
9. Khuroo MS, Kamili S. Aetiology, clinical course and outcome of sporadic acute viral hepatitis in pregnancy. J Viral Hepat 2003;10(1):61-9.

10. Tsega E, Krawczynski K, Hansson BG, Nordenfelt E. Hepatitis $\mathrm{E}$ virus infection in pregnancy in Ethiopia. Ethiop Med J 1993;31(3):173-81.

11. Kuscu NK, Koyuncu F. Hyperemesis gravidarum: current concepts and management. Postgrad Med J 2002;78(916):76-9.

12. Pal R, Aggarwal R, Naik SR, Das V, Naik S. Immunological alterations in pregnant women with acute hepatitis E. J Gastroenterol Hepatol 2005;20(7);1094-101.

13. Tsega E, Hansson BG, Krawczynski K, Nordenfelt E. Acute sporadic viral hepatitis in Ethiopia: causes, risk factors, and effects on pregnancy. Clin Infect Dis 1992;14(4):961-5. 